Extra Supplement: The Lord Is Risen Again

Author(s): Bertram Luard-Selby

Source: The Musical Times, Vol. 54, No. 840 (Feb. 1, 1913), pp. 1-8

Published by: Musical Times Publications Ltd.

Stable URL: http://www.jstor.org/stable/906094

Accessed: 07-05-2016 04:54 UTC

Your use of the JSTOR archive indicates your acceptance of the Terms \& Conditions of Use, available at

http://about.jstor.org/terms

JSTOR is a not-for-profit service that helps scholars, researchers, and students discover, use, and build upon a wide range of content in a trusted digital archive. We use information technology and tools to increase productivity and facilitate new forms of scholarship. For more information about JSTOR, please contact support@jstor.org.

Musical Times Publications Ltd. is collaborating with JSTOR to digitize, preserve and extend access to The Musical Times 

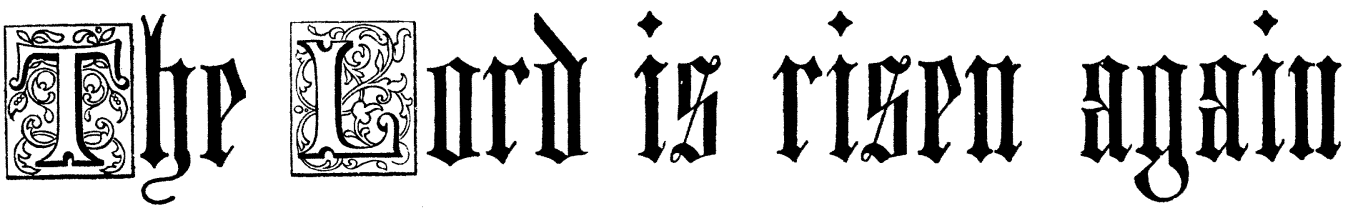

COMPOSED BY

\section{BERTRAM LUARD-SELBY.}

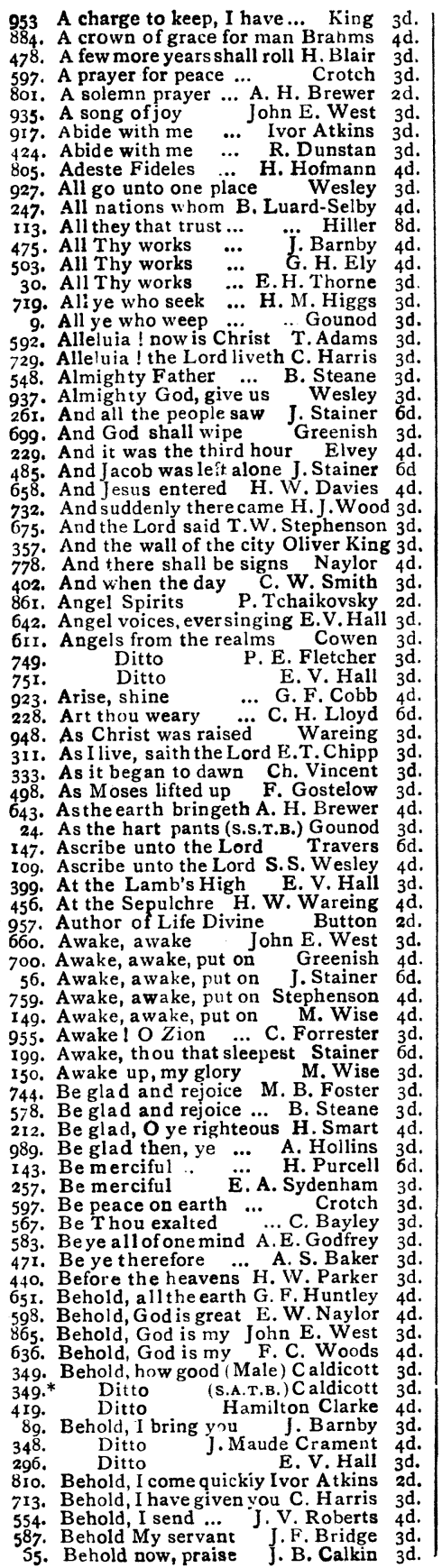

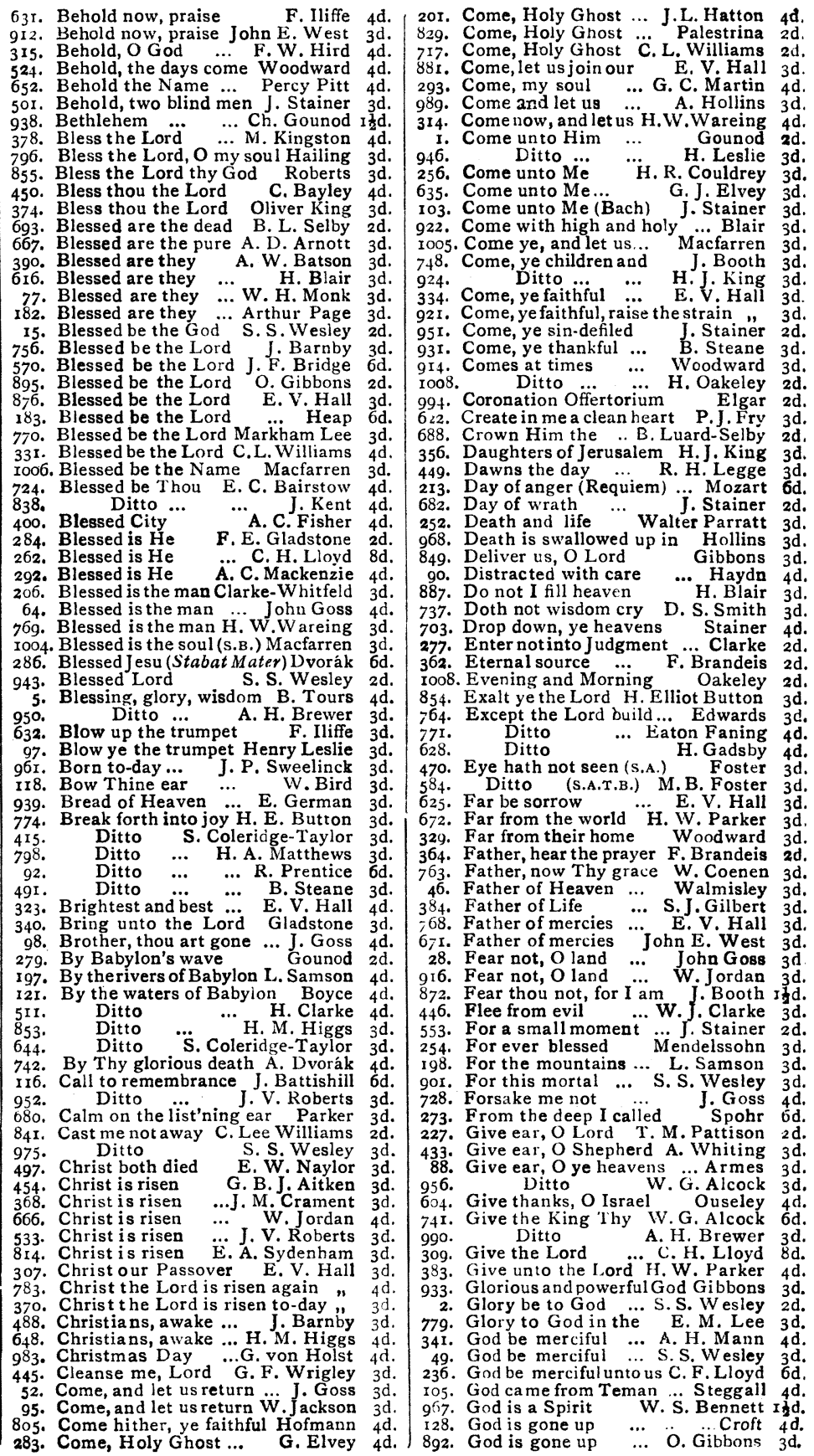

LoNDon: NOVELLO AND COMPANY, Limited. 


\section{THE LORD IS RISEN AGAIN}

SHORT FULL ANTHEM FOR EASTER

COMPOSED BY

\section{BERTRAM LUARD-SELBY.}

London: NOVEllo and Company, Limited; Nbw York: THE H. W. GRAY CO., Sole Agrnts for the U.S.A.
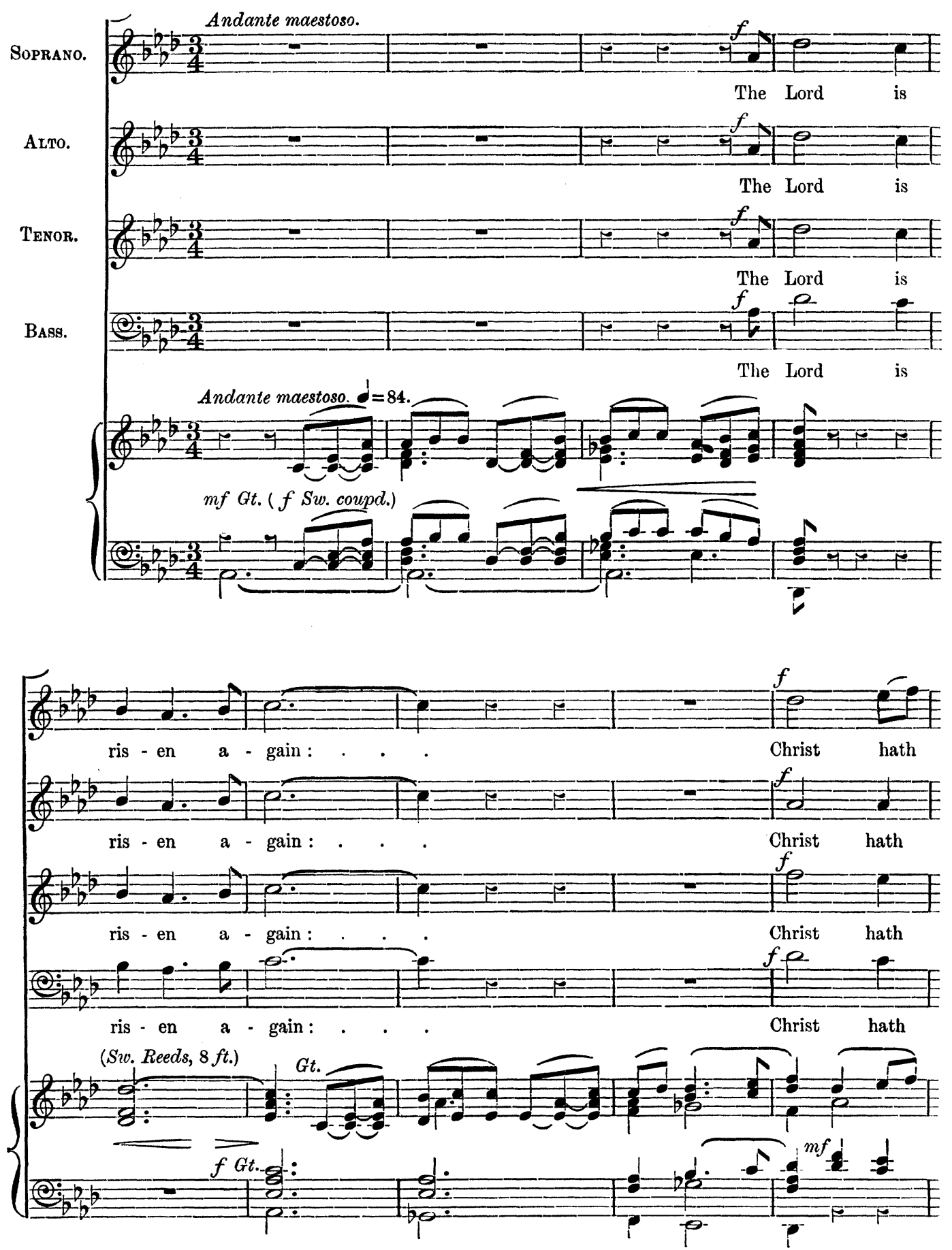

Copyright, 1913, by Novello and Company, Limited.

( 2) 
THE LORD IS RISEN AGAIN.
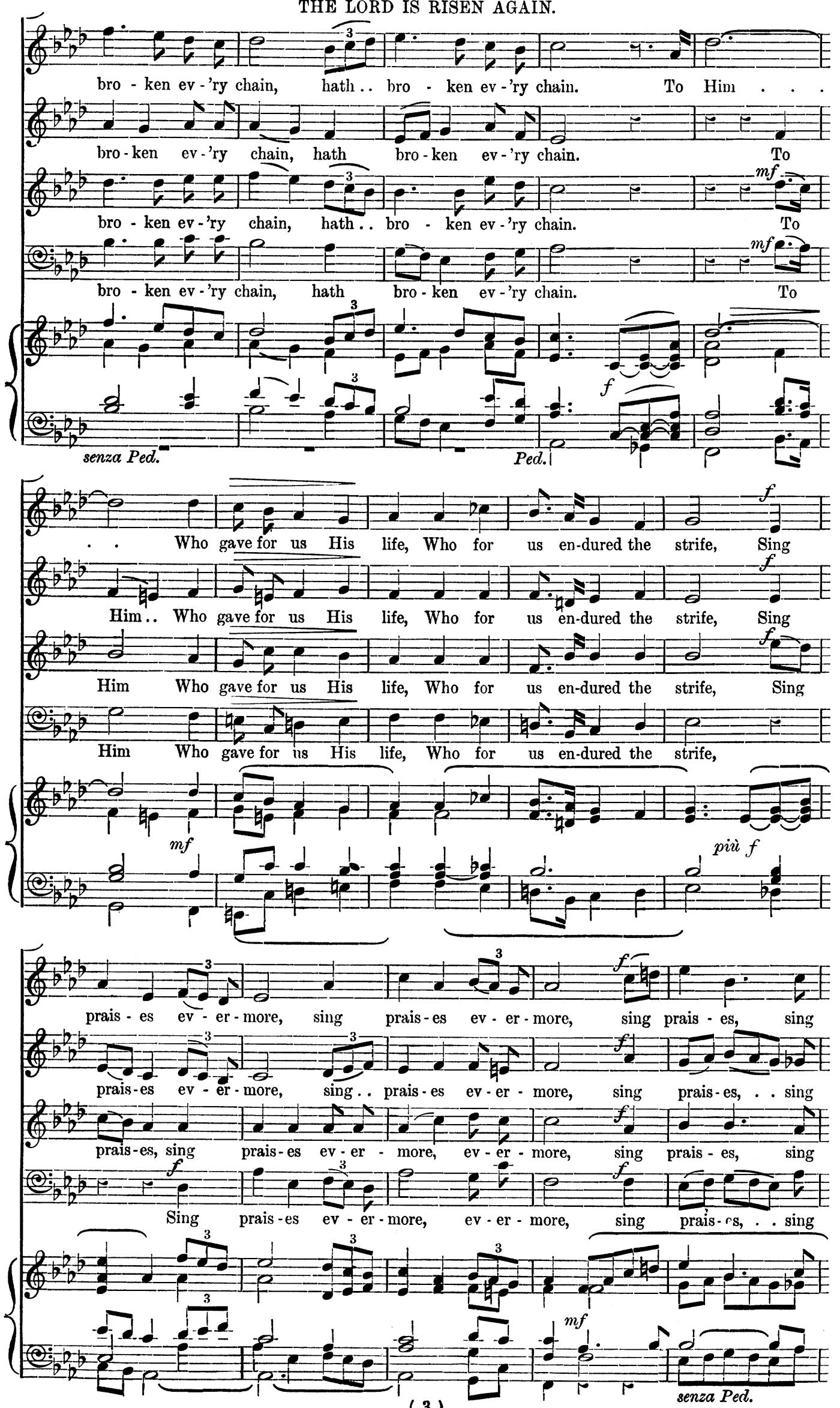
THE LORD IS RISEN AGAIN.
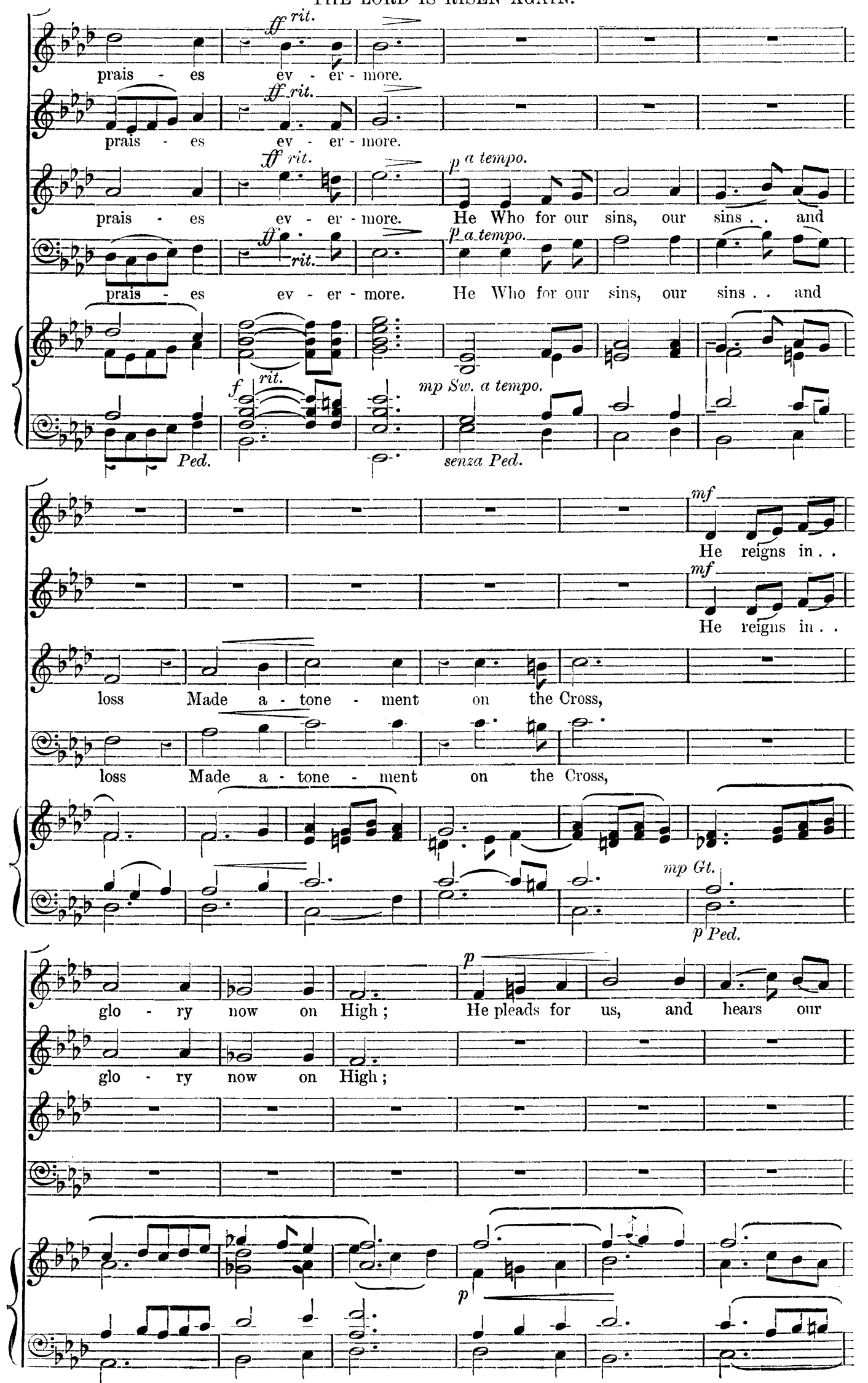

(4) 
THE LORD IS RISEN AGAIN.
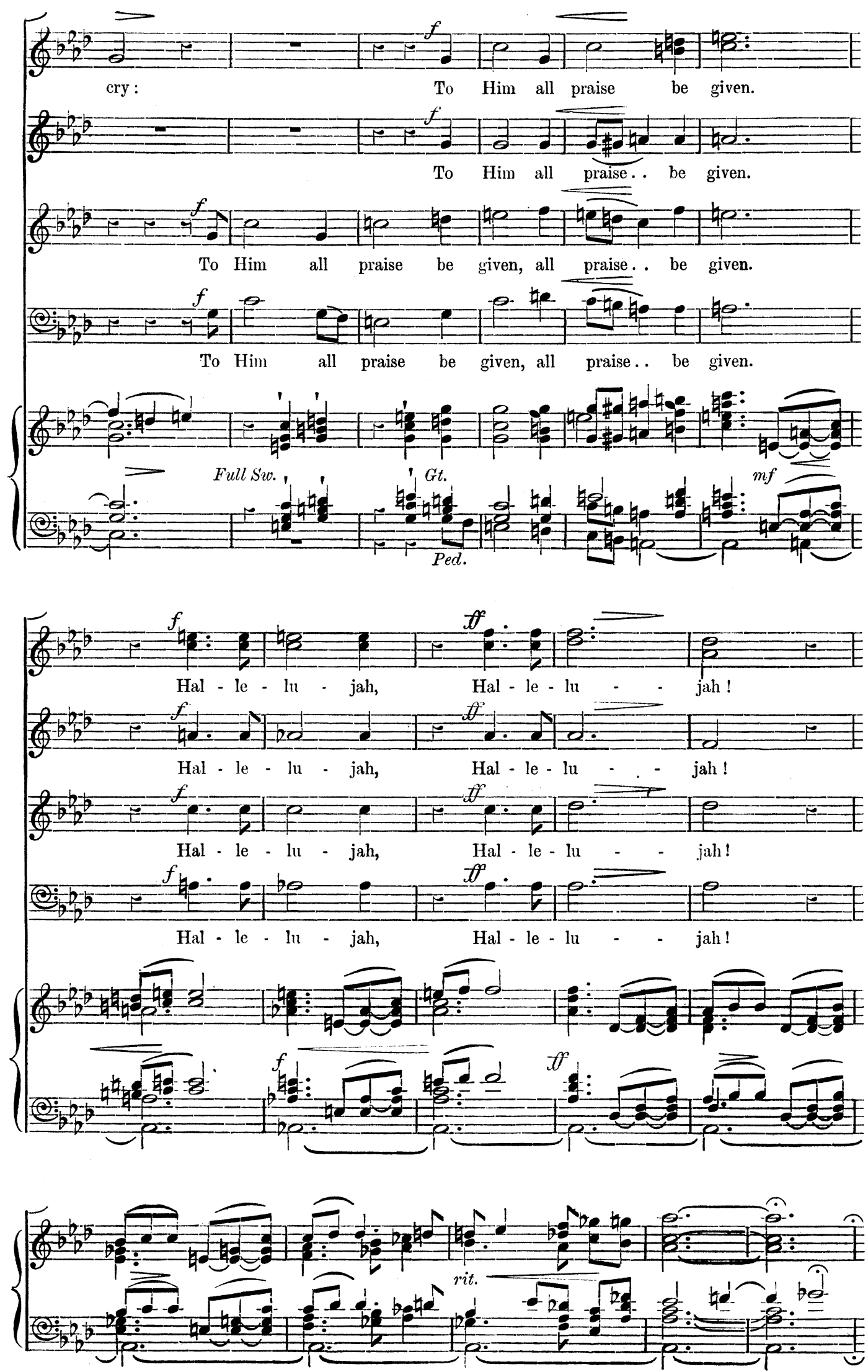

(5) 
THE LORD IS RISEN AGAIN.
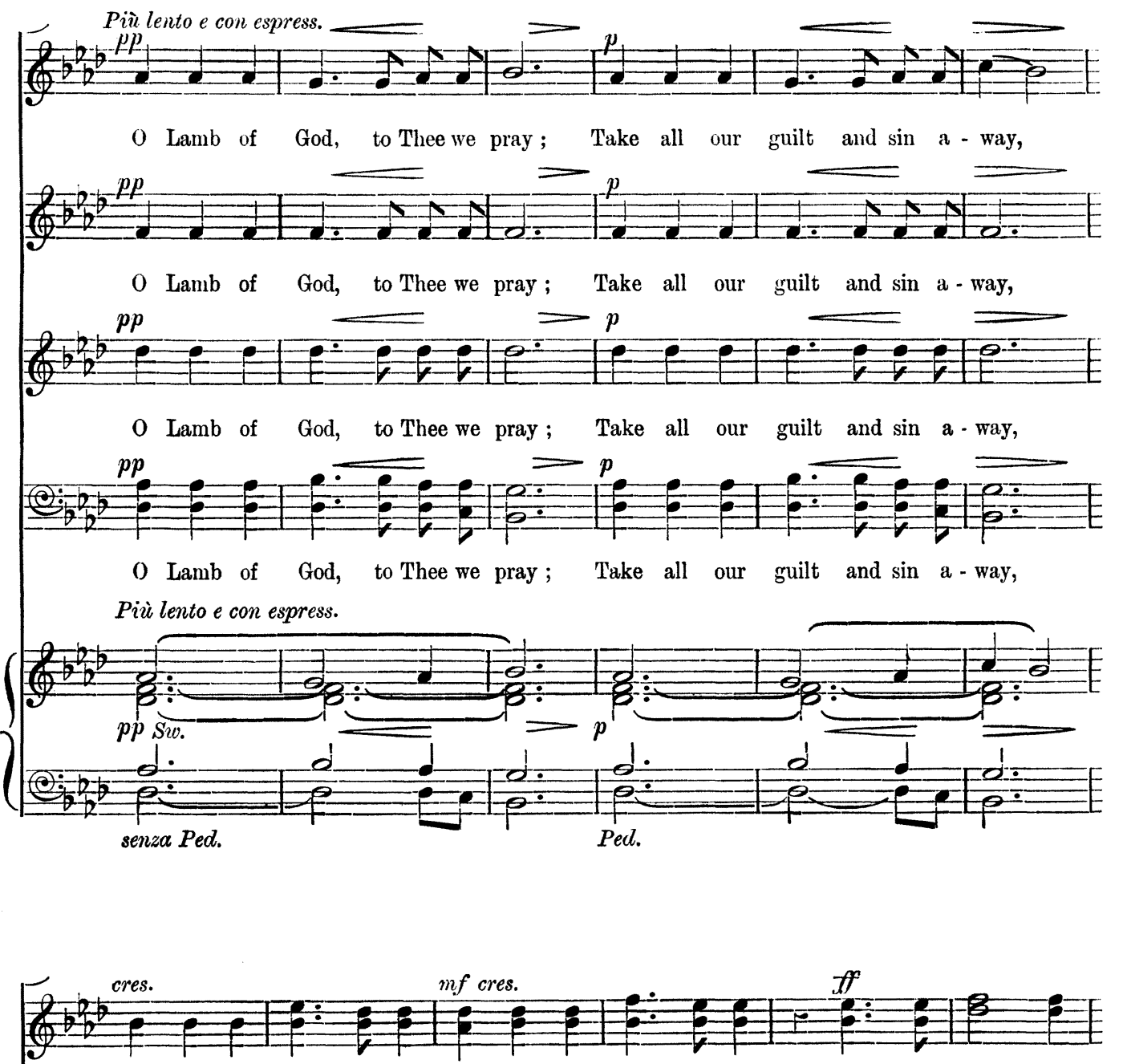

Make us to rise with Thee, make us to rise with Thee. Hal - le - lu - jah,

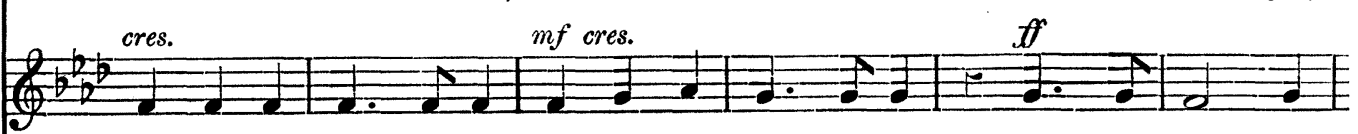

Make us to rise with Thee, make us to rise with Thee. Hal - le - lu - jah,
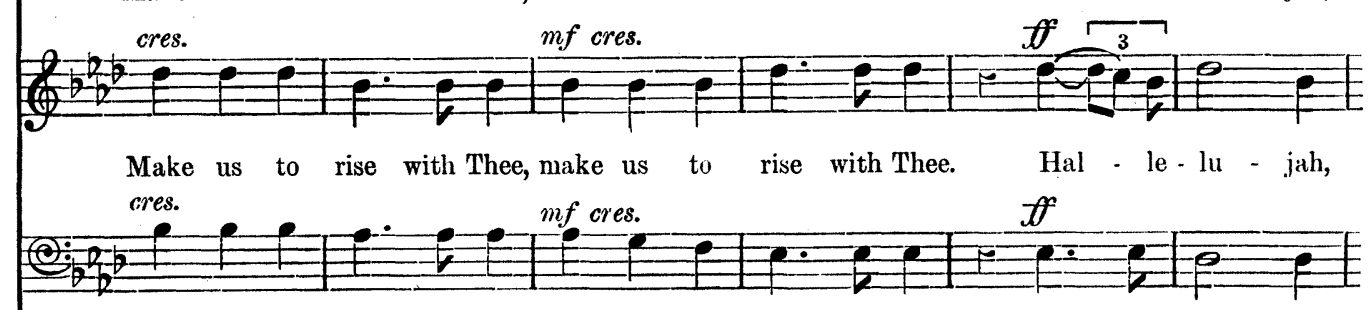

Make us to rise with Thee, make us to rise with Thee. Hal - le - lu - jah,

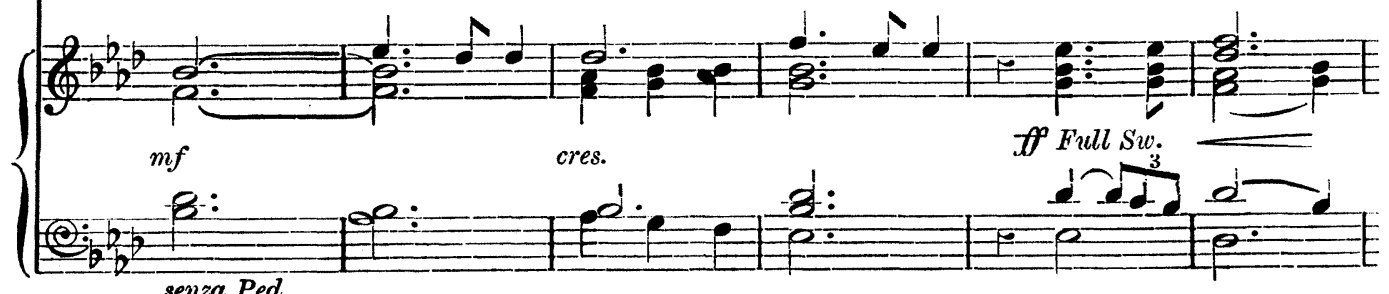

(6) 
THE LORD IS RISEN AGAIN.
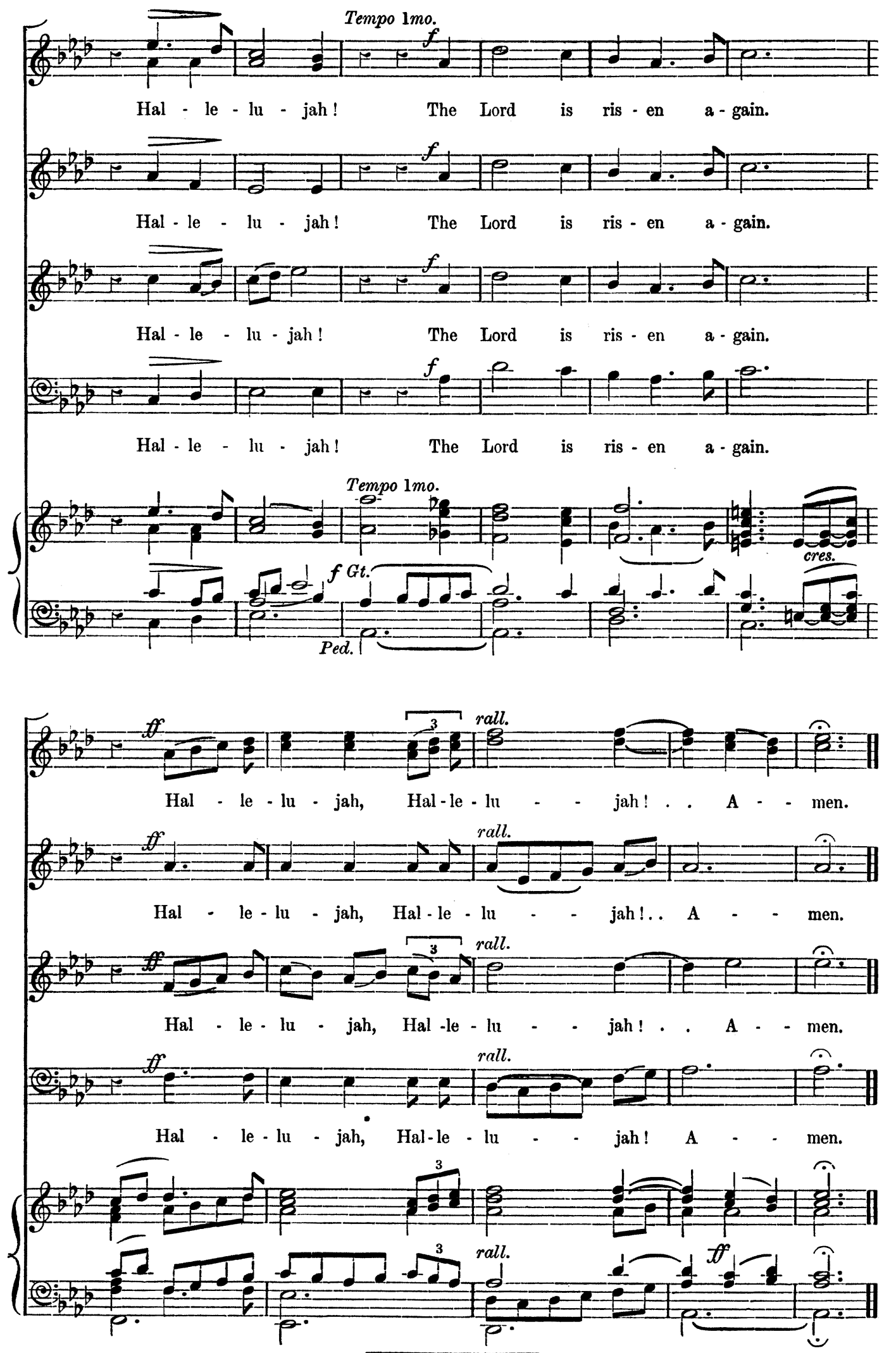

Also published in Novello's Tonic Sol-fa Series, No. 2098, price $1 \frac{1}{2} d$. 


\section{NOVELLO'S}

\section{OCTAVO EDITION OF ANTHEMS.}

864. God is gone up Walter B. Gilbert 2d. 605. God is my salvation C. F. Bowes 3d. 13I. God is our hope ... Greene 6d. 332. God is our refuge ... A. Foote $4 \mathrm{~d}$. 75. God said, Behold .... G. Macfarren 4d. 473. Ditto ... ... J. V. Roberts 3d. 342. God, that madest earth A.C. Fisher 2d. 344. God, who at sundrytimes J. H. Mee 4d. 715. God's peace is peace eternal Grieg 3d. 550. Grant, we beseech Thee M. Elvey 2d. 517. Great and marvellous J. F. Bridge 4d. 187. Great and marvellous T. Monk 3d. 223. Great is Jehovah (Male) Schubert 4d. 602. Great is our Lord ${ }^{\prime}$ M. B. Foster 4 d. 136. Great is the Lord $\ldots w$ Hayes 4 d. 708. Great is the Lord A. W. Marchant 3d. 37. Great is the Lord 813. Great is the Lord E. A. Sydenham 220. Grieve not the Holy Spirit Stainer 6o9. Guide me, O Thou H. Blair 3d. 427. Hail ! gladdening Light J. T. Field 2d 526. Hail, thou that art ... A. Carnall 4d. 560. Hail to the Christ .... J. Barnby 3d. 945. Hail, true Body ... H. Willan 2d. 382. Hallelujah! the Light Oliver King 3 d. 173. Happy is the man ... E. I'rout 8d. 1. Hark, the glad sound M. B. Foster 3 d. 909. Hark, the glad sound A. R. Gaul 3d. 45. Hark, the glad sound E. V. Hall 3d. 444. Hark! what news ... Oliver King 3 d. 404. Harvest Hymn ... F. Tozer 2d. 820. Haste Thee, O God John Shepherd $3 \mathrm{~d}$. 784. Have mercy upon me J. Barnby 2d. 535. Have mercy upon me J. Goss 4d. I013. Have Ditto ... ... E. Minshall 3d. 40I. Have mercy upon me J. Shaw 3d. 794. He sendeth the springs Wareing 4d. $\begin{array}{lll}\text { 7or. He shall swallow up } & \text { Greenish } & \text { 3d. } \\ \text { 707. He that dwelleth ... } & \text { J. Booth } & \text { 4d. }\end{array}$ B37. He that shall endure Mendelssohn 2d. 898. He that spared not His Gladst one $3 \mathrm{~d}$. 9oo. He will swallow up death Wesley I $\mathrm{I}_{2} \mathrm{~d}$. 389. Hearme when I call (Male) Distin 2d. 339. Hear my prayer $\ldots$ Mendelssohn
146. Hear my prayer $\ldots$ Ioor. Hearmy prayer $\ldots \quad$ H. Purcell 2d. 442. Hear my words C. H. H. Parry 8d. 3ro. Hear, $O$ God ... A. Friedländer 6d. 138. Hear, O beavens P. Humphreys 3 d. 94. Hear, $O$ Lord $\quad .$. John Goss 2 d. $\begin{array}{llll}\text { 139. Hear, O Lord } & \ldots & \text { F. King } & \text { 2d. } \\ \text { 162. Hear, O Lord } & \ldots & \text { F. Ouseley } & \text { 4d. }\end{array}$ 83I. Hear, O My people ${ }^{\mathrm{J}} \mathrm{J}$. Holbrooke $3 \mathrm{~d}$.

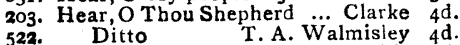
522. Ditto 77 . Hear the voice and prayer Tallis $2 \mathrm{~d}$. 773. Hearken unto me ... W. H. Bell 3 d 376. Hide not Thy face Kellow J. Pye 2d.
366. Ho! every one J.M. Crament 4 d. 366. Ho! every one J.M.Crament 4 d. 330. Holy Ghost, to earth … Dvorák 4d. 842. Holy, Lord God $\cdots$ T. Bateson 4d. 412. Honour the Lord ... j. Stainer 4d. Dito (in E flat) O. Gibbons 3d. 43. Hosanna $\ldots$ G. A. Macfarren 3d. 557. Hosanna to the Lord W. Jordan 4d. 260. How beautiful are the feet Handel 3 d. 69I. How blest are they Tschaïkowsky 4 321. How excellent is Thy ... Cowe 6r5. How great is the loving West $3 \mathrm{~d}$.

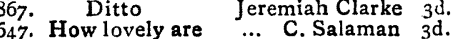
104. Ditto $\quad \ldots . .$. Spohr 8d. 766. I am Alpha $\ldots{ }^{\prime}$ Ch. Gounod $3 \mathrm{~d}$. 523. I am Alpha $\dddot{2}$ Je that liveth $\mathrm{J}$. V. Roberts 3 T. Adams 4 d. 664. I am the Resurrection ... Croft 3 d. 662. I am the Resurrection R. Rogers $4 \mathrm{~d}$. 268. I am well pleased J. Rheinberger 3 . 20. I beheld, and lo $\ldots$... Blow 6d. 80. I beheld, and lo $\cdots \quad$ c... Elvey 6d. 496. I came not to call 537. I declare to you ... Cruickshank 4 d. 68. I desired wisdom $\ldots$ J. Stainer 6d. 5I5. I do not ask, $O$ Lord ... Roberts $3 \mathrm{~d}$. 170. I have set God Hamilton Clarke 4 . 130. I have set God ... J. Goldwin $3 \mathrm{~d}$ 122. I have surely built ...... Boyce 4d. 219. I have surely built T. T. Trimnell 4d. 590. I heard a great voice G. F. Cobb 3d. 9. John Goss 2d. 7. I saw the Lord ... J. Stainer 6d. 114. I was glad ... ... 'T. Attwood 4d. 993. I was glad $\ldots . \quad \ldots$ A. H. Brewer 3 d. . I was glad ... 743. I was glad $\ldots$ C. H. H. Parry 4 d. 379. I was glad ... T. T. Trimnell 4d. 9. I was in the spirit ....... Blow 6d. 4. I will cry unto God ... H. H. King 3d. 73. I will cry unto God $\dddot{\mathrm{C}} . \mathrm{M}$. Hudson $3 \mathrm{~d}$. 502. I will extol Thee C. M. Hudson 4d. 29. I will give thanks .... J. Barnby 4d. 156. I will give thanks ...E. J. Hopkins $6 \mathrm{~d}$.
568. I will give thanks ... 15. I will give unto him $\ldots \mathrm{H}$. Blair $2 \mathrm{~d}$. 674 . I willgive you rain $\mathrm{H}$. W.W Wareing $4 \mathrm{~d}$. 225. I will go unto $\ldots$ Gauntlett 2 d. 591. I will go unto the altar C. Harris 3d. 437. I will greatly rejoice Cruickshank 4 d. 495. I will lay me down $A . C$. Edwards 3 d. 209. I will lay me down ... H. Hiles 3 H. 739. I willlift up mine eyes D. S. Smith $3 \mathrm{~d}$. 558. Ditto will love Thee J. V. Roberts $3 \mathrm{~d}$. 394. I will love Thee $\ldots$ Kingston $4 \mathrm{~d}$. 126. I will ove Thee, O Lord J. Clark 4 d. 760. I will magnify Thee J. B. Calkin 4 d. 27. I witl magnify Thee ... John Goss 3 d. 33. I will magnify Thee ... F. Iliffe 4 d. 405. I will magnify Thee Oliver King 4d. 780. W Dito Ioro. Ditto $\cdots$ A. C. H. Lloyd 3d. 929. I will magnify Thee P. W. Marchant 3d. 153. I will magnify Thee ... J. Shaw 3 d. 754. I will mention $\ldots$. A. Sullivan 6d. 575. I will not leave you $\ldots$ B. Steane $2 d$. 519. I will open rivers E. Pettman 3 d. 519. I will open rivers E. Pettman 3d. roo. I will sing a new song .... Armes od. 603. I will sing of the mercies J. Booth 3 d. 192. I will sing unto the Lord Wareing 3 d. 6. I will wash my hands Hopkins $3 \mathrm{~d}$. 7ro. If any man hath not H.W. Davies $4 \mathrm{~d}$. . If Christ be not raised Macpherson 4d. 979. If the Lord had not E. C. Bairstow 3d. 75 . If the Lord Himself W Walmisley 6d. 53. If we believe that Jesus died Goss I $\frac{1}{2} d$. 544. If ye love Me ${ }^{\cdots}$ H.. W. Wareing
789. If ye then be risen Ivor Atkins $4 \mathrm{~d}$. 469. If ye then berisen (S.A.) M. B. Foster 3d. 58. If ye then be risen ... Naylor 3d. 61. In Christ dwelleth ... John Goss 3d. 619. In every place incense John E. West $3 d$. 655. In heavenly love $\ldots$ H. Parker 3d. 403. In my Father's house Crament 3d. ro2. In sweet consent $\ldots$ E. E. Thorne 3 . 278. In that day $\ldots$.... G. Elvey 4d. 720. In the beginning C. Macpherson $4 d$. 582. In the beginning ... F. Tozer $4 \mathrm{~d}$. 89o. In the day shalt $\dddot{H}$. W. Wareing 3 d. 338. In the fear of the Lord J.V. Roberts 3d. 980. In the hour of my c. ${ }_{\text {Macpherson }}^{\text {Davies }} 4 \mathrm{~d}$. 282. In the Lord $\cdots$ C. R. Stewart 6d. 385. In Thee, O Lord $\cdots$. s. C. Taylor 3d.

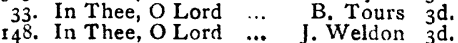
467. Is it nothing (S.A.) M. M. Foster 3d. $57 \mathrm{I}$. Is it nothing ( 4 voices) M. B. Foster $3 \mathrm{~d}$. 725. Is it not wheat-harvest $\mathrm{T}$. Adams $3 \mathrm{~d}$. 91. It came even to pass J. Barnby 6d. 23r. It is a good thing $\dddot{T}$. M. Pattison 4 d. 215. It shall come to pass $\ldots$ Garrett $6 \mathrm{~d}$. 908. Jesu, Lord of life and glory Elgar 3d. 397. Jesu, lover of my soul (Male) F. Elife 2d. 5. Jesu, Thou joy ... E. H. Davies 3 d. 844. Jesu, Thou sweetness H. J. King 3d. 904. Jesu, word of God incarnate Elgar 2d. 788. Jesus Christ is risen to-day Gaul 4d. 455. Jesus Christ is risen Oliver King $4 \mathrm{~d}$ $97 \mathrm{I}$. Jesuslives! no longer now Foster $3 \mathrm{~d}$. 6r8. Jesus of Nazareth ... G. Byrd 4d. 548. Joy in harvest ...... B. Steane 3d. 7. Judge me, O God ... Mendelssohn
677. Just Judge of Heaven
6 r. 614. Jing all glorious $\cdots \quad \ldots \quad$ j. Barnby $6 \mathrm{~d}$. 997. Ditto (4 voices) J. Barnby 4d. 581. Kings shall be thy G. C. Martin 2d. 894. Kings shall see and arise Bridge 6d. 425. Lead, kindly Light... R. Dunstan 3d. 589. Lead, kindly Light D.Pughe-Evans 3 d. 37. Lead, kindly Light... J. Stainer 4d. 706. Let all the world ... W. Wordan 4d. 132. Let God arise $\dddot{T}$ T. T. Trimnell $4 \mathrm{~d}$. 375. Let God arise 1 T. T. Trimnell 4d. 857. Let my complaint Arthur Batten 2d. 346. Let my complaint (Male) Thorne 3d. 807 Let not your heart Eaton Faning $3 \mathrm{~d}$. 438. $\quad$ Ditto $\quad \%$ v.) M. B. Foster 3d. Foster $3 \mathrm{~d}$ 438.* Let the heavens be glad M. Higgs 4 d. 226. Let the peace of God J. Stainger $4 \mathrm{~d}$. 226. Let the peace of God $\mathrm{J}$. Stainer 4d. 565. Let the righteous … R. F. Lioyd 3d. 494. Let Thy merciful ears $W$. B. Bell $2 d$. 308. Let us now praise (Male) Thorne 3 d. 308. Let us now praise (Male) Thorne
962. Lift.
96. Lift up thine eyes ... J. John Goss $6 \mathrm{~d}$.
897. Lift up your heads 18. Lit up your heads Ditto ... . L. Hopkins I Id. 409. Ditto S. Coleridge-Taylor 3d.

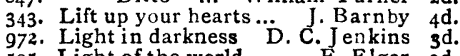
595. Light of the world ... E. Elgar 3d. 403. Lighten our darkness G. R. Vicars 2d. 393. Like as the hart Thomas Adams 3d.
D. Clarke $3 \mathrm{~d}$. 530. Lo, God, our God ... B. Haynes 3 d. 335. Lo, summer comes again J. Stainer 6d. 504. Lo! the winter B. Farebrother $3 \mathrm{~d}$. 883. Look down, Holy Dove ... Selby 3 d.

LoNdon: NOVELLO AND COMPANY, Limited. 